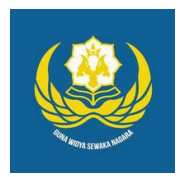

Jurnal Analogi Hukum

Journal Homepage: https://ejournal.warmadewa.ac.id/index.php/analogihukum

\title{
Status Mewaris Terhadap Anak Yang Lahir Dari Perkawinan Beda Agama
}

\author{
Ni Kadek Oktaviani*, I Ketut Widia dan I Ketut Sukadana \\ Universitas Warmadewa, Denpasar-Bali, Indonesia \\ *laksmidewi@gmail.com
}

\begin{abstract}
How To Cite:
Oktaviani, N, K., Widia, I, K., Sukadana, I, K. (2021). Status Mewaris Terhadap Anak Yang Lahir Dari Perkawinan Beda Agama. Jurnal Analogi Hukum. 3 (1). 27-31. Doi: https://doi.org/10.22225/ah.3.1.3024.27-31
\end{abstract}

\begin{abstract}
The diverse in Indonesia's society is widely open for any possibility of interfaith marriages, where interfaith marriages are Nomort strictly regulated in Indonesia Marriage-Law, causing a problem that related into the validity of marriage and in the status of inherited children that are resulting biological or adopted children and affinity from this different religion marriage. The formulation of the issue and obstacle is chose in this research is about how the legal status of the interfaith marriages according to Law Number 1 Year of 1974 and how the status inherits biological or adopted children and affinity from this different religion marriages. This research is a normative legal research by reviewing legislation and using Library Research Methods the results of the research regarding interfaith marriage in Indonesia according to Marriage Act in Indonesia are Nomort strictly regulated, the consequences of this law will lead to a dilution trough a legal obscurity and uncertainty in law. But related to marital status stated in Article 2 paragraph (1) of Indonesia Marriages Law, has referred to the laws of religion and their respective beliefs faith to determine a bond of the legal marriage. As for the interfaith couples who do the marriage through the establishment of a court then recorded in the Civil Registry Office, the marriage is considered as legitimate under the government law. Legitimate marriage is a justification for a resulting of biological or adopted children and affinity to be a legitimate child. The legal status of children born of interfaith marriages is a legitimate child provided the marriage has been registered according to the statutory regulations. Regarding inheritance resulting of biological from these interfaith marriages, the children has the right to be an heir. The Marriage Law does Nomort regulate the patrimony, but moreover are regulated in more specific in each of community religion law; customary law and other laws are basically carried out by agreement by both parties.
\end{abstract}

Keywords: different religions; inheritance rights; marriage

\begin{abstract}
Abstrak-Masyarakat Indonesia yang beranekaragam tidak menutup kemungkinan terjadinya perkawinan beda agama, dimana perkawinan beda agama tidak diatur secara tegas yang mengakibatkan timbulnya permasalahan terkait keabsahan perkawinan serta berakibat pada pewarisan. Adapun rumusan masalah yang diangkat dalam penelitian ini adalah bagaimanakah status hukum perkawinan beda agama menurut UndangUndang Nomor. 1 Tahun 1974 serta bagaimanakah status mewaris anak yang lahir dari perkawinan beda agama. Penelitian ini merupakan penelitian hukum Normatif dengan mengkaji peraturan perundang-undangan dan menggunakan studi kepustakaan. Hasil penelitian perkawinan beda agama dalam Undang-Undang Perkawinan di Indonesia tidak diatur secara tegas, akibat dari hal itu akan menimbulkan kekaburan hukum dan ketidakpastian. Namun terkait status perkawinan dimuat dalam Pasal 2 ayat (1) telah merujuk pada hukum agama dan kepercayaannya masing-masing untuk menentukan ikatan perkawinan yang sah. Adapun pasangan beda agama yang melangsungkan perkawinan melalui penetapan pengadilan kemudian catatatkan di Kantor Catatan Sipil maka perkawinan di anggap sah. Perkawinan yang sah menjadi sebab seorang anak yang dilahirkan menjadi anak sah. Status hukum bagi anak yang lahir dari perkawinan beda agama merupakan anak sah asalkan perkawinan telah dicatatakan menurut ketentuan perundang-undangan. Terkait dengan pewarisan dari perkawinan beda agama maka anak tersebut berhak sebagai ahli waris. Undang-Undang Perkawinan tidak mengatur mengenai pembagian harta, namun pengaturan yang demikian terdapat pada hukum masing-masing yang berarti hukum agama, hukum adat dan hukum lainnya pada dasarnya dilakukan atas kesepakatan oleh kedua belah pihak.
\end{abstract}

Kata kunci: beda agama; hak waris; perkawinan 


\section{Pendahuluan}

Perkawinan termasuk sebagai kebutuhan dasar (asasi) setiap manusia, yang tujuannya adalah untuk membentuk keluarga atau rumah tangga yang bahagia dan kekal berdasarkan Ketuhanan Yang Maha Esa (Erwinsyahbana, 2020). Keheterogenan masyarakat Indonesia menyebabkan adanya beberapa hukum yang mengatur mengenai perkawinan. Lahirnya Undang-Undang Nomor 1 Tahun 1974 merupakan perwujudan dari unifikasi hukum pekawinan menjawab segala keperluan mengenai aturan terkait dengan perkawinan di Indonesia. Namun, tidak memuat aturan mengenai perkawinan beda agama .

Aturan perkawinan bagi bangsa Indonesia adalah Undang-Undang Nomor 1 Tahun 1974 tentang Perkawinan, yang berlaku secara resmi sejak tanggal diundangkan, yaitu tanggal 2 Januari 1974, kemudian berlaku secara efektif pada tanggal 1 Oktober 1975, melalui Peraturan Pemerintah Republik Indonesia No. 9 Tahun 1975 tentang Pelaksanaan Undang-Undang Nomor 1 Tahun 1974 tentang Perkawinan (Asiah, 2015). Dalam Pasal 2 ayat (1) UU Nomor. 1 Tahun 1974 mengatakan perkawinan yang dilakukan atas dasar keagamaan dari pasangan beda agama, maka dikatakan sah. Hukum agama pedoman dalam melangsungkan perkawinan yang berkekuatan penuh di Indonesia yang bersifat menentukan. Maka masyarakat Indonesia di tuntut untuk tunduk terhadap hukum yang berlaku, tidak melakukan perkawinan di luar hukum agama.

Mengenai pengaturan Pasangan beda agama di Indonesia yang menyangkut sah nya perkawinan tidak ada pengaturan tegas yang melarang adanya perkawinan beda agama, maka perkawinan beda agama dapat melalui cara sebagai berikut: Indonesia

Menyiasati hukum yang berlaku di

Melalui penetapan pengadilan.

Perkawinan beda agama banyak mengundang perdebatan di masyarakat banyak pihak yang menentang terjadinya perkawinan beda agama, karena di khawatirkan perkawinan beda agama akan menimbulkan permasalahan yang sulit diselesaikan. Salah satu permasalahan yang akan timbul terkait dengan keabsahan perkawinan dan kewarisan dari perkawinan beda agama.

Berdasarkan latar belakang diatas, maka permasalahan yang ditimbulkan dapat dirumuskan sebagai berikut :
Bagaimanakah status hukum perkawinan beda agama menurut UU Nomor 1 Tahun 1974 ?

Bagaimanakah status mewaris anak yang lahir dari perkawinan beda agama?

Adapun tujuan dari penulisan ini adalah:

Tujuan umum

Untuk melaksanakan kegiatan Tri Dharma Perguruan Tinggi dalam bidang penelitian

Untuk memenuhi persyaratan guna memperoleh gelar Sarjana Hukum di Fakultas Hukum Universitas Warmadewa Denpasar.

Tujuan khusus

Untuk mengetahui status hukum perkawinan beda agama mengenai UU Nomor 1 Tahun 1974

Untuk mengetahui status mewaris anak yang lahir dari perkawinan beda agama

\section{Metode}

Tipe penelitian yang digunakan bersifat Nomorrmatif. Penelitian yang diperoleh dari hasil studi perpustakaan dengan menganalisis suatu permasalahan hukum melalui peraturan Perundang-undangan.

Sedangkan pendekatan yang digunakan adalah pendekatan PerUU dan konseptual. Pendekatan perundang-undangan mengatur semua yang terkait isu hukum dan pendekatan konseptual di peroleh dari pandanganpandangan yang memperjelas pengertian dan konsep hukum.

\section{Sumber Bahan Hukum:}

Bahan hukum primer adalah sumber utama dan isinya mempunyai kekuatan mengikat kepada masyarakat. Bahan hukum yang digunakan dalam penelitian ini sebagai berikut: Tahun 1945

UU Dasar Negara Republik Indonesia

UU Nomor 1 Tahun 1974 mengenai Perkawinan

\section{Kitab UU Hukum Perdata}

UU Nomor 23 Tahun 2002 mengenai Perubahan UU Nomor 35 Tahun 2014 mengenai Perlindungan Anak

Peraturan Pemerintah Nomor 37 Tahun 2007 mengenai Pelaksanaan UU Nomor 23 tahun 2006 mengenai Administrasi 
Kependudukan

Bahan hukum sekunder adalah berkaitan dengan memberikan penjelasan mengenai penelitian yang diantaranya adalah buku-buku yang berkaitan dengan perkawinan, tulisan para pakar hukum dan hasil laporan penelitian yang berkaitan dengan penelitian ini.

Terkait analisis bahan hukum menggunakan studi keperpustakaan setelah bahan terkumpul kemudian diolah dan dianalisis melalui interpretasi secara sistematika memudahkan pembaca untuk memahami yang penyajiannya menggambarkan secara lengkap tentang status mewaris yang berkaitan dengan rumusan masalah.

\section{Hasil Penelitian dan Pembahasan}

\section{Status Perkawinan Beda Agama Berdasarkan UU Nomor 1 Tahun 1974}

Perkawinan sebagai perbuatan keagamaan karena merupakan ibadah dan memiliki perbuatan hukum dalam bidang hukum perkawinan. Perbedaan suku, adat dan agama masyarakat tidak dapat membatasi kodrat manusia sebagai makhluk sosial yang saling membutuhkan, maka perlu pemahaman atas makna perkawinan itu sendiri di dalam sebuah ikatan perkawinan yang mengandung kesungguhan untuk hidup bersama dalam membentuk keluarga. Sehingga akan timbul hak dan kewajiban sebagai suami isteri Purwoto $\mathrm{S}$. Gandasubrata mengatakan bahwa perkawinan beda agama yang tidak diatur dalam Undangundang secara tegas (Gandasubrata, 1988).

Adapun syarat melangsungkan perkawinan yang muat dalam Pasal 6 dan 7 UU Nomor 1 Tahun 1974 sebagai berikut :

Syarat Formil, yakni mengenai aturan yang berlaku dalam melangsungkan perkawinan.

Syarat Materill, yakni syarat yang berkaitan dengan diri pribadi sesorang yang akan melangsungkan perkawinan, misalnya:

Harus ada persetujuan dari kedua belah pihak calon mempelai

\section{Syarat usia}

\section{Tidak dalam status perkawinan}

\section{Berlakunya waktu tunggu}

Djuhaendah Hasan mengatakan sahnya perkawinan hanya ada satu kemungkinan berdasarkan hukum agama, tetapi karena Indonesia masyarakatnya menganut agama yang berbeda menimbulkan keanekaragaman (Hasan, 2011). Realita di masyarakat mengenai status keagamaan yang diterima pasangan beda agama dapat dilihat dari tata cara melangsungkan perkawinan. Berdasarkan ketentuan Pasal 2 ayat 1 UU Nomor 1 Tahun 1974 harus berdasarkan hukum agama masingmasing pasangan. Perkawinan antar agama yang tidak diakui merupakan pembatas atas dasar agama dimana Undang-Undang Dasar memberikan kebebasan setiap orang untuk memeluk agama dan beribadah menurut agamanya. Ketentuan agama di masyarakat menjadikan perkawinan yang berpedoman dengan aturan masing-masing agama, maka untuk menentukan perkawinan yang sah harus berdasarkan keagamaan dari pasangan tersebut, apabila perkawinan tidak berdasarkan keagamaan dan tidak sesuai dengan aturan yang berlaku, maka perkawinan di anggap tidak pernah terjadi dan tidak ada ikatan perkawinan (Nuruddin \& Tarigan, 2004). Bagi masyarakat Indonesia yang beragama Islam, Kristen, Budha, Hindu dan Khatolik untuk melangsungkan perkawinan antar agama sebelumnya harus ada kesepakatan dari pasangan tersebut. Hukum agama mana yang akan di gunakan untuk memenuhi ketentuan dari hukum masing-masing agama agar perkawinan dapat di sahkan secara agama.

Selanjutnya Pasal 2 ayat 2 mengenai perkawinan agar dicatatakan sebagai administratif untuk memperoleh kepastian hukum dari ikatan perkawinan yang telah berlangsung berdasarkan tujuan dari perkawinan yang kekal. Dari segi sosiologis Negara tidak memberikan pengakuan atas perkawinan beda agama yang menyebabkan pasangan beda agama mencari alternatif untuk melangsungkan perkawinan beda agama sebagai berikut:

Penundukan hukum yang dilakukan berdasarkan hukum masing-masing agama, dimana salah satu pihak menundukkan diri pada salah satu hukum untuk melangsungkan proses perkawinan.

Melangsungkan perkawinan diluar negeri, dengan menyiasati hukum di Indonesia banyak pasangan menggunakan alternatif ini dengan melangsungkan perkawinan di luar negeri, kemudian mencatatkan perkawinan mereka di Indonesia paling lambat terhitung dari satu tahun perkawinan berlangsung.

Melalui penetapan pengadilan, setelah memperoleh penetapan pengadilan kemudian pasangan dapat melangsungkan perkawinan serta mendaftarkan perkawinan tersebut secara 
sah.

\section{Status Mewaris Anak yang Lahir dari Perkawinan Beda Agama}

Anak adalah dambaan bagi setiap pasangan dimana tujuan dari perkawinan merupakan memperoleh keturunan, selama perkawinan yang berlangsung berdasarkan aturan perkawinan, maka anak tersebut merupakan anak sah, sebagaimana diatur dalam Pasal 42 sampai 43. Mengenai hak anak yang diatur didalam UU anak berhak untuk beribadah sesuai dengan agamanya. Anak yang lahir dari pasangan beda agama tentu tidak akan beragama ganda maka anak tersebut dapat menentukan pilihannya terkait agama yang dianut ketika anak telah dewasa. Keanekaragaman masyarakat Indonesia dengan seiring kemajuan teknologi yang semakin berkembang menyebabkan adanya interaksi manusia satu sama lain. Perkawinan beda agama mengandung unsur yang sama dengan perkawinan pada umumnya hanya saja terdapat perbedaan dalam hal agama dan kepercayaannya, maka akan mengakibatkan timbulnya akibat hukum dalam perkawinan sebagai berikut:

Adanya hubungan hukum antara suami dan istri, perkawinan yang menimbulkan hak dan kewajiban yang sama sebagai seorang suami istri dengan posisi yang seimbang karena masing-masing memiliki tanggung jawab. Apabila perkawinan tidak di catatkan, maka akan timbul kerugian terhadap anak dan harta bersama yang sulit dibagi secara adil.

Adanya hubungan hukum antara orang tua dan anak, keturunan merupakan generasi penerus keluarga, maka perkawinan yang sah menjadi lahirnya anak yang sah untuk itu perkawinan harus dicatatkan sebagai kelengkapan administratif, bila tidak dicatatkan akan berakibat pada kewarisan serta hak-hak yang sepatutnya diterima oleh anak tersebut.

Masalah harta kekayaan, didalam hukum perkawinan terdapat dua macam harta yakni harta bersama dan harta bawaan. Apabila perkawinan tidak dicatatakan dan tidak pernah di anggap ada oleh Negara, maka sulit untuk mengajukan pembagian harta bersama ke pengadilan.

Ada dua macam pewarisan di dalam KUH Perdata yakni:

Pewarisan berdasarkan UU

Pewarisan berdasarkan surat warisan
Dalam perkawinan beda agama untuk menentukan pewarisan dilihat dari sah atau tidaknya anak yang lahir dari status perkawinan orang tuanya. Dinas Kependudukan Catatan Sipil Kabupaten Klungkung yang memiliki tugas dan wewenang mencatatkan perkawinan sesuai ketentuan Pasal 2 UU Nomor 1 Tahun 1974. Perkawinan disahkan oleh masingmasing agama dianggap sah, sedangkan perkawinan yang tidak disahkan oleh masingmasing agama, maka perkawinan tidak dapat dicatatkan. Adapun pasangan beda agama melangsungkan perkawinan melalui penetapan pengadilan, maka Kantor Catatan Sipil bertugas mencatatkan sesuai ketentuan Undang-Undang. Pencatatan perkawinan adalah sebagai bukti autentik untuk mendapatkan kepastian hukum telah terjadinya perkawinan, maka anak akan menjadi anak sah dan berhak sebagai ahli waris.

Status hukum anak dari pasangan beda agama merupakan keturunan yang sah, karena perkawinan telah dicatatkan Negara yang dilakukan sesuai dengan hukum masing-masing agama. Secara yuridis berdasarkan UndangUndang bahwa, anak tumbuh dan berkembang dari perkawinan yang sah namun beda agama, anak dapat melakukan pilihan hukum untuk dirinya sendiri terkait dengan agama yang akan dianut dan diamalkan.

Harta bersama adalah harta kekayaan yang diperoleh selama ikatan perkawinan yang sah berlangsung. Harta bersama memiliki tanggung jawab yang seimbang, maka suami atau istri tidak dapat memindahkan harta tanpa persetujuan kedua belah pihak. Apabila perkawinan telah putus akibat perceraian harta bersama harus dibagi bersama suami dan istri tersebut. Mengenai pembagian harta bersama Undang-Undang Perkawinan tidak mengatur secara rinci teknis pembagian harta bersama namun didalam Pasal 36 ayat 1 harta bersama dibagi berdasarkan pilihan hukum kedua belah pihak. Pada dasarnya dapat dilakukan dengan kesepakatan bersama oleh para pihak atas bantuan pengadilan.

\section{Simpulan}

Dari rumusan masalah yang dikemukakan serta pembahasannya, maka dapat disimpulkan sebagai berikut:

Perkawinan antar agama masih saja menjadi polemik di Indonesia karena tidak memuat aturan yang jelas mengenai perkawinan tersebut. Akibatnya timbul kekaburan hukum dan ketidakpastian. Undang-Undang Nomor 1 Tahun 1974 Pasal 2 ayat (1) telah merujuk pada hukum agama yang menentukan ikatan sah dari 
perkawinan, banyak pasangan yang tetap ingin melangsungkan perkawinan dengan agama yang berbeda dengan menempuh berbagai alternatif salah satunya dengan cara menundukan diri bersedia mengikuti prosedur perkawinan menurut agama pasangannya dan melalui penetapan pengadilan.

Status hukum bagi anak tersebut merupakan anak sah asalkan perkawinan telah dicatatkan sesuai ketentuan perundang -undangan. Anak yang lahir dari perkawinan yang sah namun berbeda agama, anak tersebut berhak untuk melakukan pilihan hukum untuk dirinya sendiri, pilihan dalam hal ini terkait dengan agama yang akan dianut dan amalkan tanpa terikat paksaan agama yang dianut orang tuanya.

\section{DAFTAR PUSTAKA}

Asiah, N. (2015). Kajian Hukum Terhadap Perkawinan Beda Agama Menurut Undang-Undang Perkawinan Dan Hukum Islam. Jurnal Hukum Samudra Keadilan, 10(2). Retrieved from https:// media.neliti.com/media/ publications/240404-kajian-hukumterhadap-perkawinan-beda-ag31c2c207.pdf

Erwinsyahbana, T. (2020). Sistem Hukum Perkawinan Pada Negara Hukum Berdasarkan Pancasila. Jurnal Ilmu Hukum, 3(1). Retrieved from https:// media.neliti.com/media/ publications/9129-ID-sistem-hukumperkawinan-pada-negara-hukumberdasarkan-pancasila.pdf

Gandasubrata, P. S. (1988). Tinjauan Mengenai Perkawinan Campuran dan Perkawinan Antar Agama. Makalah: Badan Pembinaan Hukum Nasional.

Hasan, D. (2011). Hukum Keluarga. Jakarta: Nuansa Madani.

Nuruddin, A., \& Tarigan, A. A. (2004). Hukum Perdata Islam di Indonesia, Studi Kritis Perkembangan Hukum Islam dari Fikih UU Nomor. 1/1974 sampai KHI. Jakarta: Prenada Media. 